\title{
Report on the Third Interdisciplinary Meeting of Chairs and Institutes of Security In Szczecin on 25-26 September 2019
}

\author{
Aleksandra Raba-Schulze ${ }^{1}$
}

On 25-26 September 2019 the Third Interdisciplinary Meeting of Chairs and Institutes of Security took place. The event's organizers were the Institute of Political and European Studies of the University of Szczecin, the Institute of the European Strategy and Security, the Research Group on Security of Local Communities, with cooperation from the Faculty of Political Science and Security Studies of the Nicolas Copernicus University in Toruń, and the Department of Security and Protection of Classified Information of the Marshall's Office of the West Pomerania Voivodship, the Department of Security and Crisis Management of the West Pomerania Voivodship Office. Patronage over the meeting: His Magnificence Vice-Chancellor of the University of Szczecin prof. dr hab. Edward Włodarczyk, Marshall of the West Pomerania Voivodship Olgierd Geblewicz, President of the City of Szczecin Piotr Krzystek, West Pomerania Voivodship's Governor Tomasz
Hinc, Commander of the Multinational Corps Northeast Lieutenant General dr Sławomir Wojciechowski, Voivodship Police Commissioner in Szczecin Chief Superintendent Jacek Cegieła.

It is worth noting that the discussed Meeting was a continuation of the previously established cooperation of Chairs and Institutes of Security and their academic employees who investigate security issues. The main subject of the Meeting was the problem of implementing the Act Law on higher education and science, including an analysis of consequences and challenges of new regulations, as well as an exchange of thought and knowledge on key security categories. The discussed September Meeting was attended by the total of 30 delegates representing renown and leading academic and research centres in Poland. The Meeting's Proceedings were held at Hotel Vulcan and the Waste Disposal Facility in Szczecin. This formula and place of the meeting created

${ }^{1} \mathrm{PhD}$ student at the Institute of Political Science and Security Studies of the University of Szczecin. ORCID ID: 0000-0003-4847-6131. 
a comfortable space for the participants to exchange views and interesting, fruitful discussions.

The plenary session was preceded by a presentation from the Vice-Chancellor of the University of Szczecin prof. dr hab. Edward Włodarczyk and the Dean of the Faculty of Social Sciences dr hab. Renata Podgórzańska, professor of the University of Szczecin. Following this, the panel discussion started, which was moderated by dr hab. Jarosław Piątek, professor of the University of Szczecin, which was attended by the Commander of the Multinational Corps Northeast in Szczecin Lieutenant General dr Sławomir Wojciechowski and prof. dr hab. Jerzy Konieczny.

Afterwards, the Meeting participants visited the Vulcan Training Centre located in Hotel Vulcan. It is worth emphasizing that this is the only place in Poland where civilians can get training on how to save their own life in an emergency situation in water. The Meeting participants were presented a helicopter stimulator HUET, which is used for training for evacuation in the event of an emergency landing on water.

After a short coffee break the Meeting participants took part in another panel, the subject-matter of which concerned security as a research subject. Moderation of the panel was taken up by dr Tomasz Czapiewski and the session was opened by a presentation by dr hab. Juliusz Piwowarski, associate professor, entitled "Definition of the environment of security, a broad approach". He pointed to a problem, key to studies on security, concerning a redefinition of the environment of security, at the same time promoting its extended concept. The next presentation by dr Bogdan Chmieliński was devoted to teaching in fields of study related to security. The speaker referred to programmes and content of education in these disciplines. The next presentation entitled "Security in the political discourse of the Third Republic of Poland" by dr Paulina Polko addressed a quantitative and qualitative analysis of selected elements of the political discourse in 1989-2019. After the session, the speakers and participants of the Meeting presented their views and proposals concerning the discussed subject matter.

The second day of the Meeting began with a panel concerning an agglomeration and its institutions for human security, needs vis-a-vis capabilities, and was conveyed by Deputy-President of the City of Szczecin Michał Przepiera and dr Szczepan Stempiński, Plenipotentiary of the President of the City of Szczecin for security matters.

The next thematic block chaired by dr Cezary Guźniczak and dr Szczepan Stempiński focused on the dimension of state security. Dr hab. Janusz Gierszewski, professor of the Pomeranian Academy in Slupsk, presented his paper as first which was entitled "Social dimension of human security - implications and paradigms 
of changes". In his speech the author attempted to characterize the social dimension of human security in the system, educational, institutional and local area. He also pointed to the forms and methods of education for security. Then dr Martyna Seroka presented a paper on immissions from areas reserved for the needs of state security. The author presented her research on the impact of noise and other immissions from areas associated with sate security, such as military training grounds or shooting ranges, on areas allocated to residential buildings. The next speaker was dr Tomasz Czapiewski, whose paper concerned public policy instruments in the area of security as seen in the example of voivodship self-government in Poland. The author presented analyses of public policy instruments in two categories: substantive and procedural, based on legal acts, programme documents and real forms of activity of voivodship self-government in the field of security. The next speech, entitled "Selected threats to state security" by dr Olga Filipiak shed light on some threats influencing the decrease in consumers' sense of security. The speaker pointed to, inter alia, economic, cultural, ecological, social and legal threats. The proceedings of this session were closed by dr Magdalena Redo's presentation on the importance of state financial security for national security.

After a short coffee break the Meeting participants moved on to the last part of the proceedings, the subject-matter of which concerned contemporary trends and perspectives of the international security practice. The last thematic panel was chaired by dr hab. Andrzej Wojtaszak, professor of the University of Szczecin. The proceedings were opened by a presentation of prof. dr hab. Artur Gruszczak entitled "Savagery as a form of combat: anthropology of a post-modern war", in which the speaker reflected on the nature of contemporary conflicts and presented the problem of pragmatics of security in the light of relativization of ethical norms and inclinations for barbarization of contemporary conflicts. The panel chair, dr hab. Andrzej Wojtaszak, professor of the University of Szczecin presented a paper entitled "The role of the B9 Group in shaping the concept of NATO's eastern flank" in which he emphasized that the voice of nine countries is stronger especially towards the aggressive policy of the Russian Federation, which leads to strengthening the attitudes of deterrence and defence being at the same time open to political dialogue. A presentation from the next speaker, dr hab. Elżbieta Posłużna, addressed the problem of ideologically motivated violence in the context of research on compensational transformations of values. The author shed light on the characteristics, mainly from the psychological side, of the phenomenon specified as "the activity of lone wolves". The next speaker, dr hab. Daniel Kucharek, pointed to the policy of enhancing security of Poland in the aspect 
of financial possibilities of the Ministry of National Defence. The paper entitled "Developing anti-access abilities, AntiAccess/Area Denial, as an integral element of the strategy of deterrence" presented by dr hab. Adam Radomyski shed light on the issues of developing anti-access abilities by the Russian Federation and its impact on the limitation of freedom of movement of the NATO forces. Whereas dr hab. Grzegorz Ciechanowski, professor of the University of Szczecin, in his presentation, showed an analysis of capabilities of the Polish Navy ships since 1990 which have participated in operations of the allied forces and NATO. The next paper entitled "Changes in the environment of security of Lebanon in the $21^{\text {st }}$ century" presented by dr Piotr Lotarski brought some insight into the environment of security of Lebanon in the $21^{\text {st }}$ century/the matter in question. In his presentation, the author pointed out that ambitions of Iran, who supports the Lebanese Hezbollah and controls Iraq and Syria, may contribute to making an attempt to take over control in Lebanon. Then dr Piotr Bajor discussed current determinants and changes in shaping the security policy of Ukraine. The paper from the next speaker, dr Andrzej Wawrzusiszyn, addressed the system of cross-border security. The author pointed out that the system of cross-border security is a set (that can be identified within the system of national security) of authorities and public administration bodies, methods and modes of action, interrelated and complementary elements separated from state structures in order to ensure the security of the national border - its inviolability and efficiency and creation of conditions for unrestricted and stable state development in many spheres of its activity. The proceedings were closed by dr Artur Staszczyk, who presented the issues of cyber defence as a priority of the European Union's Common Security and Defence Policy.

The last point of the agenda of the Third Interdisciplinary Meeting of Chairs and Institutes of Security was a visit in the Waste Disposal Facility. The Meeting participants visited one of the most modern incineration plants in Europe and one of Szczecin's biggest investment. This visit was a confirmation of the importance of cooperation of academic centres with the outside environment. 